\title{
GAYA KOMUNIKASI KEPIMPINAN PENTADBIR AKADEMIK: SATU KAJIAN GENDER DAN WACANA
}

(Academic Leadership and Communication Style: A Study of Gender In Discourse)

\author{
KESUMAWATI ABU BAKAR
}

\begin{abstract}
ABSTRAK
Artikel ini mengkaji wacana 3 pentadbir akademik wanita dalam mempamerkan keindividuan mereka dan membentuk individu individu yang bertentangan dengan stereotaip gender dalam konteks wacana mesyuarat pengurusan. Selain daripada memahami gaya komunikasi individu pentadbir wanita, kajian ini juga bertujuan untuk memperlihatkan variasi dalam gaya komunikatif yang wujud dalam satu kumpulan gender dan etnik yang sama, seterusnya mengkaji semula paradigma gender dikotik yang lazim digunakan dalam kajian indivi dan gender. Data kajian ini diperolehi dari enam interaksi dalam mesyuarat yang telah dirakam tanpa sebarang campur tangan daripada pengkaji. Berpandukan klasifikasi enam fungsi indivi dalam mesyuarat (Goodale 1987; Barnard 2018), analisis tertumpu kepada kaedah-kaedah yang digunakan oleh tiga pentadbir wanita untuk (1) mencapai matlamat mesyuarat (2) dan mengawal perbincangan dalam mesyuarat. Hasil dapatan kajian menunjukkan beberapa strategi komunikatif yang digunakan oleh subjek kajian ini adalah 182ndividual bentuk perilaku gender yang mungkin dicetuskan oleh keperluan institusi, kepimpinan serta indivi individuality.
\end{abstract}

Katakunci: Komunikasi; Gender; Kepimpinan; Kajian wacana

\begin{abstract}
This article examines the discourse of Malay administrators as representations of individuality and feminine identities that are seen to conform to as well as challenge gender stereotypes within the context of academic management meetings. Apart from analyzing their communication styles, this study also aims to show the variation that exists within the same gender and ethnic group, and to further question the dichotic gender paradigm commonly used in language and gender studies. The data were obtained from six meeting interactions recorded without any intervention from the researcher. Using the classification of six language functions in meetings (Goodale 1987; Barnard 2018), the analysis focuses on the strategies used by the three administrators to (1) achieve the agenda of the meeting (2) and to manage the discussion and interaction between members. The results show that some of the communicative strategies used by the subjects of this study are the antithesis of gender behavior that may be triggered by factors such as institutional needs, leadership demands and personality.
\end{abstract}

Keywords: Communication; Gender; Leadership; Discourse Analysis 


\section{PENGENALAN}

Laporan tahunan wanita Grant Thornton International (2018) melaporkan jumlah pembabitan wanita dalam pengurusan kanan telah meningkat sejak 20 tahun terakhir. Di Malaysia pula peratusan wanita dalam pengurusan kanan meningkat kepada $28 \%$ tahun ini berbanding $24 \%$ pada tahun 2017, seterusnya membentuk jumlah yang tertinggi sejak 2011. Walaupun terdapat peningkatan bilangan wanita pada kedudukan pengurusan dalam lebih banyak bidang pekerjaan dan perniagaan, secara menyeluruh jumlah peratusan pembabitan adalah masih kecil dibandingkan lelaki.

Pengurusan adalah sangat penting kepada sesebuah organisasi. Pengurusan yang cekap dari segi perancangan, pengorganisasian dan pengawalan sumber manusia dan kewangan berupaya menggerakkan sesebuah organisasi ke arah pencapaian matlamat dan seterusnya kejayaan. Hakikatnya, pengurusan sesebuah organisasi melibatkan individu lelaki dan wanita. Apabila perkara ini dikaitkan dengan peratusan pembabitan wanita yang rendah berbanding lelaki, isu sama ada terdapat perbezaan atau persamaan berasaskan gender dalam keupayaan untuk mengurus dan berkomunikasi secara berkesan, secara tidak langsung menjadi sesuatu yang signifikan (Goman 2016; Merchant 2012).

Konsep perbezaan gender ini secara lazimnya menjadi faktor utama dalam menerangkan dan mengklasifikasikan perbezaan gaya kepimpinan dan komunikasi dalam pengurusan organisasi. Biasanya penjelasan gaya adalah berdasarkan andaian budaya dan sosial berkaitan dengan perilaku gender. Beberapa kajian menyokong andaian yang tradisional, berdasarkan stereotaip budaya, bahawa wanita mempunyai orientasi kerjasama yang lebih berbanding dengan lelaki dan lelaki pula lebih berdaya saing daripada wanita (Kivikangas et al. 2014). Lazimnya, apabila seorang wanita berinteraksi, dia dijangkakan lebih bekerjasama dalam komunikasi, berkolaborasi dan sensitif terhadap perasaan seseorang, manakala lelaki pula lebih tertumpu kepada cara mengawal keadaan, memperlihatkan status dan mengekalkan kebebasan. Seorang wanita yang menepati acuan perilaku gender dihargai keupayaannya menjadi feminin, tetapi sekiranya beliau mencabar mana-mana tuntutan stereotipikal, beliau akan dikritik dan dianggap sebagai maskulin dan seterusnya digelar 'wanita besi' (Mazidah 2013). Perbezaan dalam cara berkomunikasi dan perbuatan akan mewujudkan perselisihan di antara apa yang diharapkan daripada seorang wanita dengan apa yang diperlukan oleh sebuah pengurusan. Secara tidak langsung pengurus wanita disubjekkan kepada penelitian tingkahlaku berdasarkan gender. Kesannya, apabila corak komunikasi bertentangan dengan stereotaip gender, kelakuan mereka dianggap menyimpang dari norma.

Tujuan kajian ini adalah untuk mengenalpasti dan menerangkan strategi komunikasi yang digunakan oleh pemimpin akademik wanita dalam menguruskan mesyuarat dan seterusnya melihat fitur-fitur kesesuaian atau penyimpangan dari norma komunikatif gender. Hasil dapatan kajian dijelaskan melalui teori Butler's Gender Performativiti yang mana teori ini menjelaskan bahawa gender bukan hanya merujuk kepada representasi dualiti feminin dan maskulin, tetapi ianya satu konsep yang boleh berubah melalui pengulangan perlakuan berdasarkan pengertian budaya mengenai norma tingkah laku feminin dan maskulin dalam masyarakat. Oleh itu, kajian ini mengistilahkan gender sebagai sesuatu yang subjektif, yang terbentuk dari perlakuan wacana (discursive acts) berterusan setiap lelaki atau wanita yang dipengaruhi oleh anggapan dan persekitaran sosial setiap individu. Dengan membayangkan gender sebagai performatif, ia membentuk variasi perlakuan feminin dan maskulin yang ada kalanya cara bercanggah dengan jantina seseorang individu. Teori ini juga mencakupi pelbagai konstruksi dan representasi gender yang lebih luas yang seterusnya menghasilkan semula dan mempersoalkan kategori gender binari. 


\section{KAJIAN LITERATUR}

\section{Teori Gender dan Performativiti}

Penghuraian secara ringkas mengenai pembangunan teori gender adalah penting untuk memudahkan pemahaman teori Performativiti Gender oleh Butler (1990). Secara tradisi, pembahagian manusia kepada dua jantina yang berdasarkan perbezaan biologi antara lelaki dan wanita telah dilihat sebagai kategori identiti yang semulajadi dan bersesuaian (Hines et al. 2014). Oleh itu, secara biologinya, lelaki dianggap sebagai semulajadi maskulin, dengan penampilan, karakter dan sifat yang bersesuaian dengan maskulin manakala wanita pula direpresentasikan dengan penampilan, karakter dan juga sifat yang bersesuaian dengan sifat feminin. Kebijakan berkomunikasi juga memperkukuhkan lagi kepercayaan bahawa lelaki dan wanita secara semulajadi memiliki dan menggunakan ciri-ciri komunikasi gender yang berbeza yang disampaikan melalui tingkah laku mereka. Walaupun anggapan bahawa perbezaan gender antara lelaki dan wanita ini boleh dikatakan simplistik, Sistem binari ini mampu membantu dalam pemahaman dan penjelasan disebalik kesalahfahaman antara lelaki dan wanita.

Sehingga tahun 1990, kajian awal terhadap gender dan cara komunikasi telah menghasilkan dikotomisasi dua pendekatan yang dikenali sebagai model Dominasi vs Perbezaan. Polarisasi ini telah mewujudkan satu gambaran yang sempit terhadap keseluruhan keseluruhan senario bahasa dan gender, dengan menganggap bahawa tingkah laku lelaki adalah prototipikal dan wanita adalah substandard, manakala pencirian wanita dan lelaki sebagai milik dua budaya yang berbeza telah gagal untuk menerima kewujudan variasi atau sub-budaya gender lelaki dan wanita dan kepelbagaian yang wujud di dalamnya. Tahun 90-an walau bagaimanapun menyaksikan perkembangan teori yang memihak kepada pendapat anti-essentialist gender yang bukan sahaja mencabar takrif konsep jantina, tetapi juga telah dibuktikan kecacatan korelasi sifat-sifat peribadi (iaitu jantina) dengan bentuk kelakuan ucapan yang khusus. Justeru, hubungan antara bahasa dan gender dapat difahami sebagai satu konstruk budaya perilaku yang dipelajari, yang juga bergantung kepada konteks.

Butler mempertikaikan pengertian gender dan melalui hujah-hujah yang meyakinkan beliau menyatakan tidak ada perkara yang bersifat semula jadi didalam pembentukan gender. Kesemulajadian badan fizikal dipersoalkan dan gender dilihat sebagai satu bentuk perlakuan yang berulang-ulang dan bukannya ciri-ciri intrinsik yang diwarisi (1990). Hal ini membawa kepada idea bahawa identiti gender adalah satu konstruk sosial yang boleh berubah menurut perlakuan dari segi pertuturan, pemakaian dan fitur fizikal. Ini adalah ruang yang bebas diteroka, di mana perbezaan lakuan boleh dilaksanakan dan diubah untuk memenuhi permintaan khusus masyarakat dan situasi sosial. Ini seterusnya menawarkan kerangka teori yang baru untuk mengkaji gender dan identiti sebagai pengulangan ritual (ritualized repetition).

Perilaku gender pada kebanyakan masa sering kali diolah sebagai tindak balas terhadap persekitaran, amalan dan keperluan yang berbeza mengikut masa dan disebabkan itu, identiti gender sentiasa dalam proses penyesuaian (Scheller-Boltz 2017). Oleh itu, konsep feminin dan maskulin seharusnya dilihat sebagai satu konsep yang tidak statik tetapi sebagai konstruk dan ruang yang berkembang (Harrison 2008). Hal ini seterusnya membawa kepada pertindihan kepelbagaian fitur maskulin dan juga feminin di dalam perlakuan seseorang.

\section{Gender Dan Komunikasi Dalam Organisasi}

Di dalam teori pengurusan organisasi telah berkembangnya kajian yang memfokuskan pada diskriminasi gender di tempat kerja. Keprihatinan yang jelas terhadap isu gender, komunikasi dan kesamarataan peluang telah berkembang dari tahun 90an. Hasil kajian telah menyoroti kepentingan komunikasi untuk memahami diskriminasi seksual, yang seterusnya 
memperlihatkan komunikasi sebagai satu proses pelbagai aspek (multi-faceted) yang melibatkan pelbagai cara langsung atau tidak langsung dalam penyampaian makna. Tinjauan literatur ke atas wanita dalam pengurusan juga menekankan usaha untuk mengenal pasti dan mengatasi rintangan terhadap kemajuan wanita di tempat kerja dan perhatian telah diberikan kepada peranan komunikasi dalam kejayaan dalam organisasi (Roa et al. 2018). Walaupun peranan dan definisi gender telah berubah, cara pemikiran tradisional masih mempengaruhi tingkah laku komunikasi sebahagian besar masyarakat. Bagi mereka yang disosialisasikan dengan norma gender wanita tradisional, komunikasi fungsinya untuk mewujudkan dan mengeratkan hubungan sesama individu. Sebaliknya, tujuan komunikasi di antara lelaki adalah untuk menonjolkan identiti dengan mempamerkan autonomi dan kawalan serta menghiburkan orang lain (Tannen 2007).

Stereotaip gender mempunyai komponen deskriptif serta preskriptif yang menentukan tindakan dan perlakuan lelaki dan wanita. Contohnya, wanita seharusnya mengasuh dan menghindari dominasi, dan lelaki seharusnya menjadi pelaku dan menghindari kelemahan. Hasil kajian mendapati seseorang dinilai secara negatif apabila kelakuan bertentangan dengan stereotaip gender (Mayer 2018). Tetapi realitinya, terdapat banyak variasi dalam perlakuan identiti seseorang sehingga mustahil untuk dikategorikan sebagai berkelakuan 'maskulin' ataupun 'feminin'. Walaupun terdapat individu yang menepati peranan gender yang ditetapkan, majoriti mempamerkan sebaliknya. Tingkah laku kita, dipengaruhi oleh konteks persekitaran dan tugas, telah menunjukkan bahawa 'kewanitaan' dan 'maskuliniti' mutlak mustahil dilakukan. Dalam konteks perlakuan gender, kebanyakan wanita dan lelaki mempunyai pelbagai bentuk kemahiran komunikasi dan pertuturan, bergantung pada situasi, tujuan dan peranan.

Hasilnya, terdapat kepelbagaian yang luas dalam gaya komunikasi dan amalan setiap individu. Setiap variasi perlakuan meruntuhkan dan melemahkan nilai dominan masyarakat yang dibentuk oleh stereotaip gender. Pandangan Butler disokong oleh penyelidikan yang menyerlahkan kewujudan pelbagai strategi yang berkaitan dengan konsep maskulin dan feminin dalam repertoir ucapan peserta yang merangkumi pelajar kejuruteraan kepada pengurus institut awam dan swasta (Bahiyah 2003; Gaunt 2013, Koenig 2018). Pengunaan ciriciri komunikasi maskulin dan feminin tidak semata-mata dipengaruhi oleh gender seseorang tetapi sebagai cara untuk menunjukkan autoriti, solidariti dan menyelesaikan tugas tertentu seperti mencari penyelesaian, menutup topik, mengatur dan mengawal masa percakapan. Adalah penting untuk kita menerima persamaan dan variasi dalam amalan komunikasi yang wujud pada setiap lelaki dan wanita. Ciri-ciri maskulin dan feminin harus dilihat sebagai ciriciri komunikasi yang pelbagai dan tingkah laku yang boleh digunakan untuk memenuhi keperluan yang berbeza, pada masa yang tertentu dan juga dengan individu yang berbeza.

Gender dan keperluan organisasi telah menimbulkan pelbagai tuntutan yang bercanggah dengan stereotaip gender dan disebabkan ini cara komunikasi pentadbir wanita yang kompleks menyediakan ruang untuk kajian ciri-ciri komunikasi dan hubungannya dengan konstruksi identiti gender. Bahagian seterusnya mentakrifkan dan menerangkan ciri-ciri yang dikaitkan dengan konsep feminin dan maskulin dalam konteks komunikasi.

\section{Konsep Maskulin Dan Feminin}

Adalah penting untuk membezakan antara sifat-sifat biologi dan psikologi gender. Secara biologinya, Hofstede (1991) menggunakan istilah lelaki dan wanita; untuk konstruk sosial, gender merujuk kepada konsep maskulin dan feminin. Konsep maskulin dan feminin relatif dan tidak mutlak; seorang lelaki boleh berkelakuan feminin dan seorang wanita pula berkelakuan maskulin (Hofstede 1991). Terdapat trend umum mengenai pembahagian peranan gender. Lelaki diharapkan bersikap tegas, kompetitif dan lasak sementara wanita lebih 
mementingkan hubungan dan persekitaran (Hofstede 1991). Oleh itu, maskuliniti selalunya dikaitkan dengan ketegasan dan persaingan dan femininiti dengan pemeliharaan dan keprihatinan terhadap hubungan dan persekitaran.

Seseorang individu yang mempamerkan ciri-ciri maskulin cenderung untuk menjadi seorang yang tegas dengan sifat berdikari yang kuat (Kim 1995) dan mempunyai keupayaan untuk membuat keputusan sendiri. Sifat berdikari ini mempunyai hubung kait dengan dimensi individualisme-kolektifisme Hofstede (1991) yang mana individu tersebut tidak diklasifikasikan oleh ahli kumpulan tersebut tetapi diklasifikasikan melalui karakteristik luaran individu tersebut. Oleh itu, menurut Marcus and Kitayama in Kim (1995), individual yang berdikari dan mempunyai kebebasan akan lebih tertumpu kepada pencapaian matlamat. Kepentingan sendiri melebihi kepentingan mana-mana kumpulan (contohnya keluarga, rakan sekerja, dsb). Oleh itu, akan sentiasa wujud keinginan untuk menonjol dan menguasai persekitaran. Justeru, individualis melihat tingkah laku yang pasif dan pemalu satu kelemahan.

Seseorang yang mempamerkan sifat-sifat feminin yang kognitif, lebih cenderung berkumpulan dan bertumpu ke arah pemeliharaan keharmonian perhubungan. Individu ini lebih prihatin terhadap perasaan, keperluan, kehendak dan keutamaan orang lain daripada diri sendiri. Kesalingbergantungan ini dilabel sebagai kolektivis oleh Hofstede (1991) yang juga mengatakan bahawa sifat mementingkan diri sendiri merupakan satu kelemahan.

Walau bagaimanapun, sifat semula jadi manusia adalah kompleks dan berbeza dari dalam pelbagai situasi. Adalah perkara biasa bagi seseorang untuk mempamerkan autoriti dalam satu situasi dan kesalingbergantungan diri dalam situasi yang lain. Ramai penyelidik (Gill 1998; Kachel et al. 2016) telah menyedari kelebihan pada seseorang yang boleh mengadaptasi ciri-ciri komunikasi feminin dan maskulin dalam pertuturannya. Tanggapan terhadap feminin dan maskulin seharusnya tidak boleh dilihat sebagai satu yang bercanggah tetapi melengkapi satu sama lain. Dalam komunikasi, keseimbangan dan adaptasi adalah penting. Seseorang perlu mempunyai keupayaan dan kemahiran untuk menyesuaikan cara dan menggabungkan ciri-ciri berkomunikasi yang berbeza bergantung konteks situasi.

Jadual 1. Ciri-ciri Maskulin dan Feminin yang mempengaruhi Gaya Komunikasi

\begin{tabular}{ll}
\hline Ciri-ciri Maskulin & Ciri-ciri Feminin \\
\hline Bebas & Saling bergantung \\
\hline Penekanan pada 'saya' & Penekanan pada 'kita' \\
Tegas dan bersungguh-sungguh, bercita-cita tinggi & Perundingan dan berorientasikan kumpulan \\
dan kuat fizikal & Memupuk dan menitik beratkan hubungan \\
Berorientasikan pencapaian dan berdaya saing &
\end{tabular}

\begin{tabular}{ll}
\hline Keperluan untuk menguasai & Keperluan untuk kelulusan \\
\hline $\begin{array}{l}\text { Mengawal dan menguasai keadaan 186espon } \\
\text { Bekerja dengan bertujuan untuk memenuhi objektif } \\
\text { peribadi }\end{array}$ & $\begin{array}{l}\text { Mengambil berat tentang pendapat yang lain } \\
\text { bekerja dengan bertujuan untuk mencapai objektif } \\
\text { organisasi }\end{array}$ \\
\hline Fokus yang Berorientasikan - tugas & Fokus kepada perhubungan sosial \\
\hline Mengambil berat dengan satu cara (kejelasan) & $\begin{array}{l}\text { Prihatin dalam menghadapi sokongan, hubungan } \\
\text { interpersonal } \\
\text { Keperluan orang lain, dan hubungan seseorang } \\
\text { dengan mereka } \\
\text { (Prihatin untuk tidak melukakan perasaan pendengar, } \\
\text { kebimbangan untuk meminimumkan pengenaan) } \\
\text { Bertujuan untuk perjanjian dan cuba untuk bertindak } \\
\text { balas kepada keperluan semua orang }\end{array}$
\end{tabular}




\begin{tabular}{ll}
\hline $\begin{array}{l}\text { Menyelesaikan konflik dengan cara berdebat dan } \\
\text { bersaing }\end{array}$ & $\begin{array}{l}\text { Menyelesaikan konflik dengan perundingan dan } \\
\text { kompromi }\end{array}$ \\
\hline $\begin{array}{l}\text { Melihat konflik dari segi hak-hak individu yang perlu } \\
\text { dihormati dalam hubungan }\end{array}$ & $\begin{array}{l}\text { Mengandaikan bahawa hubungan antara diri dan } \\
\text { orang lain dan rangka penyelesaian konflik dari segi } \\
\text { Melihat pada peraturan dan prinsip, untuk } \\
\text { hubungan }\end{array}$ \\
$\begin{array}{l}\text { menyelesaikan konflik. Penilaian dibuat dari segi } \\
\text { menunjukkan toleransi, belas kasihan dan responsif }\end{array}$ \\
$\begin{array}{l}\text { logik dan rasional dan sering mengabaikan keperluan } \\
\text { orang lain }\end{array}$ & $\begin{array}{l}\text { kepada orang lain } \\
\text { penekanan terhadap persefahaman dan komunikasi } \\
\text { melalui cara mendengar dan bertutur dan bertutur } \\
\text { dan mendengar dan didengar }\end{array}$ \\
& (Hofstede 1991; Kim Min Sun 1995) \\
\hline
\end{tabular}

Kepentingan Mesyuarat Dalam Pentadbiran Akademik

Rasional disebalik pemilihan mesyuarat sebagai konteks kajian wacana ini berdasarkan fakta yang menyatakan bahawa pentadbir akademik menghabiskan sebahagian besar daripada masa mereka dalam mesyuarat yang berjadual dan yang tidak berjadual (Lundquist and Misra 2016). Penemuan ini adalah berdasarkan kepada bukti kajian empirikal daripada kaedah soal selidik dan catatan harian daripada 285 pentadbir yang dipilih secara rawak daripada Universiti Nigeria dan Britain (Titus Oshagbemi 1998). Secara puratanya, jumlah jam bekerja untuk pentadbir akademik ialah 41-43 jam seminggu. Sebanyak 44\% daripada masa tersebut dihabiskan untuk kerja hakiki (termasuk membaca kertas kajian, menulis, memberi markah tugasan dan menyediakan bahan kursus). 25-29\% daripada masa tersebut digunakan untuk mesyuarat berjadual dan 7-11\% untuk mesyuarat tidak berjadual. Secara kasarnya, jumlah peratus masa yang diluangkan untuk mesyuarat ialah 32-40\% seminggu.

\section{Struktur Mesyuarat}

Cara seseorang mengendalikan mesyuarat mencerminkan kebolehan dan kemahiran berurusan dan potensi sebagai seorang pemimpin. Penilaian sistematik terhadap keberkesanan pengurusan mesyuarat, kemahiran dan tingkah laku komunikasi perlu untuk memastikan kejayaan dan keberkesanan setiap mesyuarat yang diadakan. Oleh sebab itu keupayaan dan kemahiran yang dimiliki oleh seorang pengurus diinterpretasikan sebagai simbol kecekapan, keyakinan dan kejayaan ataupun sebaliknya (Bakic-Tomic et al. 2015). Mesyuarat adalah pertemuan bersama (secara amnya) tiga atau lebih individu untuk bertukar maklumat secara terancang dan membincangkan isu-isu yang berbangkit sebelum membuat keputusan, menyelesaikan masalah, dll. Secara umum terdapat dua agenda dalam mana-mana mesyuarat. Agenda yang pertama adalah untuk menangani kandungan hakiki termasuk merangka strategi dan perubahan positif untuk mencapai matlamat dan objektif mesyuarat. Agenda yang kedua ialah untuk memenuhi keperluan emosi, contohnya perasaan dan harapan peserta (Rubin and Brown 1975). Keseimbangan antara dua agenda ini perlu ada untuk menjadikan sesuatu mesyuarat itu berjaya, secara intelektual dan emosional. Untuk ini, seorang pemimpin memerlukan kebijaksanaan dan fleksibiliti dalam berkomunikasi untuk mencapai matlamat, dalam masa yang sama juga mengambil kira perasaan ahli-ahlinya. 


\section{PENTADBIR AKADEMIK}

Dalam kajian ini, istilah pentadbir akademik merujuk kepada ahli akademik yang memegang jawatan pentadbiran dan pengurusan dalam sistem organisasi pendidikan tinggi (Kalargyroy and Woods 2009). Jawatan tersebut termasuklah Pengarah Kanan, Pengarah, Timbalan Dekan, Ketua Jabatan dan Pengurus. Tugas-tugas semula jadi sebagai pentadbir akademik juga melibatkan tugas pentadbiran dan pengurusan seperti membentangkan cadangan kepada senat, menyediakan belanjawan, menghadiri mesyuarat formal dan bukan formal, memberi kuliah, membuat penyelidikan dan kerja-kerja perundingan (Chen 2010). Pentadbir akademik dikenalpasti memiliki (i) sifat-sifat peribadi seperti kecerdasan, bervisi, dan berintegriti (ii) kebolehan interpersonal seperti persefahaman, bersikap terbuka dan bekerjasama dan (iii) kemahiran pengurusan teknikal seperti penyelesaian masalah, pencapaian matlamat institusi, membuat keputusan dan menyelesaikan sebarang konflik (Balyer and Ozcan 2017).

\section{METODOLOGI KAJIAN}

Kajian ini melibatkan tiga pentadbir wanita dalam domain pengajian tinggi di Malaysia. Persoalannya ialah, mengapa tumpuan diberikan kepada wanita Melayu? Selain daripada mengurangkan pembolehubah etnik, wanita Melayu lebih memenuhi jawatan pembuatkeputusan dalam institut pendidikan tinggi awam berbanding kumpulan etnik yang lain di Malaysia. Oleh itu, gaya komunikasi mereka menyediakan sumber data primer yang penting untuk mengkaji peranan bahasa dan hubungannya dengan gender identiti. Selain itu, objektif kajian ini adalah untuk mempamerkan perbezaan atau variasi dalam gaya komunikasi yang wujud dalam satu gender dan kumpulan etnik yang sama dan seterusnya mengesahkan konsep femininiti yang pelbagai dalam tingkah laku pertuturan.

Ketiga-tiga pentadbir wanita Melayu ini berkerja di fakulti yang berbeza di Universiti Kebangsaan Malaysia.

Jadual 2. Profil 3 Pentadbir Akademik Wanita

\begin{tabular}{|c|c|c|c|c|}
\hline & Umur & $\begin{array}{c}\text { Latar belakang } \\
\text { pendidikan }\end{array}$ & $\begin{array}{c}\text { Tahun dalam Posisi } \\
\text { Kepimpinan }\end{array}$ & Saiz Jabatan \\
\hline P1 & 49 & $\begin{array}{l}\text { AMK, GSM, MBBS, } \\
\text { MHPEd, AM (kelayakan } \\
\text { luar negara) }\end{array}$ & 6 & $\begin{array}{l}7 \text { akademik dan } 3 \text { staf } \\
\text { pengurusan }\end{array}$ \\
\hline $\mathbf{P 2}$ & 43 & $\begin{array}{l}\text { SmSa (UKMalaysia), } \\
\text { MA, PhD (kelayakan } \\
\text { luar negara }\end{array}$ & 3 & $\begin{array}{l}9 \text { akademik dan } 1 \text { staf } \\
\text { pengurusan }\end{array}$ \\
\hline P3 & 43 & $\begin{array}{l}\text { BEc, MBA, PhD } \\
\text { (kelayakan luar negara) }\end{array}$ & 3 & $\begin{array}{l}10 \text { akademik dan } 1 \text { staf } \\
\text { pengurusan }\end{array}$ \\
\hline
\end{tabular}

Data

Data terdiri daripada transkripsi enam interaksi dalam mesyuarat yang dirakam tanpa sebarang campur tangan daripada pengkaji. Transkripsi ini dihasilkan mengikut konvensi yang telah ditetapkan (Schiffrin 1995) dalam usaha untuk menghasilkan semula interaksi in-situ yang 
dianalisis dalam kajian ini. Kebenaran untuk membuat pemerhatian terhadap mesyuarat yang dijalankan mematuhi syarat-syarat yang ditetapkan oleh setiap ketua. Oleh kerana isu yang dibentangkan bersifat rahsia maka topik-topik yang dibincangkan tidak akan didedahkan dalam perbincangan dapatan. Jumlah purata masa berlangsungnya setiap mesyuarat tersebut ialah lebih kurang 2 jam 30 minit dan jarak masa antara kedua-dua mesyuarat setiap pentadbir adalah 1 atau 2 bulan.

\section{Kaedah Analisis}

Kaedah yang digunakan untuk analisis strategi komunikasi pentadbir akademik ini ialah kaedah klasifikasi, penerangan dan penginterpretasian yang teliti.

Berikut adalah kaedah analisis yang digunakan:

a. Memilih dan mengklasifikasikan ujaran-ujaran berdasarkan enam fungsi bahasa dalam mesyuarat (Goodale 1987; Barnard 2018). Tujuan pemilihan dan penumpuan terhadap enam fungsi bahasa ini adalah berdasarkan kaedah-kaedah lazim yang digunakan oleh ketiga-tiga pentadbir wanita untuk (1) mencapai matlamat mesyuarat (2) mengurus dan mengawal perbincangan.

Enam fungsi bahasa dalam konteks mesyuarat adalah seperti berikut:

1. Memulakan mesyuarat

2. Menyoal

3. Membuat cadangan

4. Membentang dan menyokong pendapat

5. Bersetuju dan tidak bersetuju

6. Berkompromi

b. Kaedah ketua melibatkan analisis strategi komunikasi dan interpretasi konfigurasi linguistik ujaran dengan merujuk kepada sama ada ianya menepati atau menyimpang dari norma komunikasi dan tingkah laku gender (Hofstede 1991; Kim Min Sun 1995) yang diramalkan. Justeru itu, penemuan seterusnya akan mengesahkan atau menyangkal persoalan kajian ini.

\section{DAPATAN KAJIAN DAN PERBINCANGAN}

Berikut adalah satu gambaran keseluruhan hasil dapatan kajian berkenaan enam fungsi dan struktur ujaran ketiga-tiga pentadbir.

\section{Memulakan Mesyuarat}

Dalam keenam-enam pertemuan, diperhatikan bahawa hubungan asimetris antara pentadbir dan ahli yang lain terjalin semasa fasa memulakan mesyuarat melalui formalisasi peranan ketua berbanding ahli, pengesahan agenda, penetapan giliran laporan oleh ahli dan arahan tindakan selanjutnya.

Walau bagaimanapun, perbezaan terletak pada tahap keformalan ucapan pembukaan mereka. Pentadbir 1 (P1) mempunyai kecenderungan untuk bersikap santai dalam pembukaannya melalui ucapan seperti "Shall we start?"(boleh kita mula), dan cara spontan dalam tindakannya mengubah giliran 'okay, we skip audit and kualiti'. Pentadbir 2 (P2) bagaimanapun kelihatan lebih formal dalam kedua-dua permulaan ucapannya yang diujarkan mengikut cara Islam dan Melayu "Assalamualaikum dan Selamat datang ke JBMC yg ke 28". 
Pentadbir 3 (P3) sebaliknya kurang formal atau agak santai dalam mesyuarat pertamanya tetapi formal dalam pertemuan kedua. Walau bagaimanapun, kesantaian adalah disebabkan oleh ketidakhadiran sebahagian besar ahli yang menukarkan mesyuarat tersebut kepada perbincangan tidak formal. Namun, perbezaan dalam tahap formaliti tidak memberi kesan negatif terhadap hubungan asimetri antara pentadbir dengan ahli yang lain.

\section{Menyoal}

Soalan merupakan strategi yang efektif dalam mewujudkan dan mempamerkan kuasa dan yang paling kerap digunakan oleh ketiga-tiga pemimpin dalam melaksanakan urusan

(1) memulakan mesyuarat, contohnya 'shall we start?' (boleh kita mula?)

(2) memulakan topik, contohnya 'What about the one-day seminar' (seminar sehari, bagaimana pengerusi?)

(3) menamatkan topik, contohnya 'this one is done eh? (Ini dah selesai eh)

(4) memulakan dan menghentikan giliran, contohnya 'ada apa-apa lagi masalah?'

(5) mendapatkan maklumat, contohnya 'untuk apa ini?' dengan memulakan bahagian pertama soal-jawab

(6) mengurus dan memantau kemajuan topik dengan cara mengawal dan membimbing penutur ke arah pencapaian objektif mesyuarat.

Walau bagaimanapun, perbezaan dalam penyoalan dapat dilihat dari cara soalan diaju dalam bentuk pencelahan atau pintasan (interruption). Sebilangan besar pencelahan boleh didapati dalam pertuturan P1. Soalan-soalan P1 dengan cepat diselitkan ke dalam giliran penutur sebelum penutur tersebut melengkapkan giliran dan ucapannya. Keadaan ini biasanya menamatkan giliran penutur dan memberikan giliran percakapan kepada P1. Statusnya sebagai ketua dan pengetahuannya seolah-olah menjustifikasikan pintasan. P2 juga dilihat mengenakan beberapa soalan yang berbentuk pintasan untuk tujuan penjelasan maklumat. Walaupun pintasan dibuat di tengah-tengah giliran penutur semasa, P1 dan P3 tidak dapat mengubah topik yang sedang dibincangkan. Tidak ada pintasan yang diperhatikan dalam data P3. P3 dilihat memulakan ujarannya hanya selepas penutur semasa menamatkan gilirannya dalam kedua-dua mesyuarat formal dan tidak formal.

\section{Membuat Cadangan}

Fungsi cadangan digunakan oleh P1 dan P2 sebagai salah satu strategi untuk menutup topik. Kedua-duanya membuat kesimpulan terhadap topik berkaitan kemajuan dengan mencadangkan beberapa aktiviti atau tugas-tugas yang boleh dijalankan pada masa akan datang. Cadangan ini juga berfungsi sebagai maklum balas terhadap apa yang telah dibincangkan dan seterusnya menjadi isyarat dalam proses penutupan topik. Tindakan ini juga mengunjurkan beberapa aktiviti pada masa hadapan yang dikendalikan oleh ahli-ahli lain yang disahkan oleh ketua sebagai orang yang berkuasa dalam mesyuarat.

Walau bagaimanapun, perbezaan di antara P1 dan P2, terletak pada penyusunan cadangan mereka. Cadangan P1 lazimnya dibuat dalam bentuk imperatif atau perintah, manakala P2 akan menggunakan frasa seperti "would'nt it be better if" yang mana jika diterjemahkan menjadi "ada rasanya lebih baik". Cadangan P2 menandakan fleksibiliti, yang memberi ruang untuk penambahbaikan. Hasil bagi kedua-dua gaya menghasilkan pelbagai bentuk maklum balas dari ahli. Cadangan P1 biasanya diikuti dengan persetujuan ahli, manakala cadangan P2 diikuti dengan cadangan ahli-ahli lain dahulu sebelum berakhir dengan persetujuan bersama. Struktur cadangan P3 mempunyai persamaan dengan struktur ujaran P2. 
Perbezaan di antara kedua-dua pemimpin boleh dilihat melalui reaksi ahli. P3 dilihat telah menerima reaksi yang tidak diduga dalam beberapa situasi. Penolakan cadangan yang dilakukan oleh ahli secara tidak langsung menyebabkan mesyuarat berpanjangan. Walaubagaimanapun, penolakan yang dibuat dengan cara bijaksana dan berhemat menunjukkan rasa hormat ahli-ahli terhadap A3. Penolakan ini memperlihatkan sikap terbuka dan berterus terang ahli dengan P3 dalam memberikan maklum balas yang negatif dalam perbincangan.

\section{Membentang Pendapat}

Giliran dan monolog yang panjang dalam membentangkan pendapat banyak dikaitkan dengan demostrasi kuasa. Pendekatan yang digunakan oleh pemimpin dalam menyuarakan pendapat atau idea menyumbang kepada giliran yang panjang dan monolog yang kerap dalam mesyuarat. Pendekatan deduktif P1 dalam perbincangan menunjukkan pengenalan langsung idea yang diikuti dengan penyokongan hujah yang terperinci. Pengenalan langsung bertujuan untuk menjelaskan kesesuaian dan relevansi idea dan maklumat. Pendekatan ini juga bertujuan untuk melibatkan ahli-ahli dalam proses membuat keputusan. Dapat dilihat hubungan langsung autoriti P1 dengan kawalan idea dan topik dalam wacana deduktif dan kekerapan monolog beliau dalam kedua mesyuarat.

Walaupun perbentangan idea P2 dan P3 mengikut pendekatan deduktif, ucapan mereka sentiasa diselang-selik dengan cadangan atau soalan dari ahli-ahli yang lain. Kedua-dua pentadbir ini memberi penekanan kepada kerjasama kumpulan, yang membentuk satu proses rundingan. Penemuan ini menyokong idea bahawa gaya komunikasi feminin memberi keutamaan kepada kesinambungan perbincangan dengan penerimaan sumbangan idea satu sama lain (Spoelma 2018). Interaksi kolaboratif berdasarkan hujah dan penaakulan membawa kepada keputusan bersama dalam perbincangan P2 dan P3.

\section{Bersetuju dan Tidak Bersetuju}

Seterusnya, fungsi bersetuju dan tidak bersetuju memainkan peranan penting dalam mengekalkan dan mempamerkan kuasa. P1 lebih cenderung dalam menggunakan persetujuan yang kukuh seperti "itu betul dan lebih sistematik" dan "Jangan datang dengan speaker yang pertama" dalam perbincangannya dengan ahli-ahli. Sebaliknya, P2 nampak lebih seimbang dalam bantahan atau ketidaksetujuan sebagai tindak balas kepada permintaan yang tidak munasabah sahaja. Bantahan P2 dilihat sering berdasarkan keputusan bersama kumpulan dan bukan berdasarkan pendapat sendiri.

Persetujuan dan ketidaksetujuan P3 sentiasa bersifat diplomatik melalui penyataan kemungkinan yang disokong dengan alasan yang kukuh, seterusnya memperlihatkan fleksibiliti P3 terhadap perubahan dan pendapat ahli lain. Walau bagaimanapun, keputusan muktamad biasanya dilakukan berdasarkan persetujuan bersama dan pertimbangan kumpulan. Penekanan yang berterusan terhadap 'kami' menunjukkan kepada perbincangan dan pendekatan yang berorientasikan kumpulan dalam membuat keputusan.

\section{Berkompromi}

Perlakuan berkompromi dapat diperhatikan dalam keenam-enam perbincangan. Dua pandangan yang berbeza akan dikemukakan, setiap satunya diikuti dengan penaakulan yang sesuai. Rundingan berdasarkan kesesuaian dan pengalaman lepas berlaku di kalangan ketigatiga pemimpin dan ahli-ahli mereka, yang berakhir dengan kompromi di antara dua idea. Sikap 
berkompromi membentuk asas penetapan keputusan oleh ketiga-tiga pentadbir. Berkompromi boleh dilihat sebagai salah satu strategi pengukuhan kuasa pentadbir dalam mesyuarat.

\section{CIRI-CIRI MASKULIN DAN FEMININ DALAM GAYA KOMUNIKASI P1, P2 dan P3}

Seterusnya, enam strategi di atas akan dianalisis dalam konteks ciri-ciri maskulin dan feminin. Gaya berkomunikasi tiga pemimpin ini menunjukkan perbezaan dari segi ciri-ciri feminin dan maskulin dalam setiap fungsi bahasa yang digunakan.

P1 kerap menggunakan ciri-ciri maskulin melalui interaksi yang berorentasikan objektif dengan ahli-ahlinya. Ini termasuk penggunaan 'tidak/tidak boleh' dalam percanggahan, pencelahan dalam giliran, penguncian (latching) sebagai strategi pengambilalihan topik dan penyoalan untuk mengawal pengembangan topik. Strategi-strategi ini membentuk penguasaan perbincangan melalui pendekatan deduktif dalam perkongsian pendapat. Hal ini juga menyumbang kepada pengagihan yang tidak sama rata terhadap giliran dan masa antara P1 dengan ahli-ahli lain. Tambahan pula, kekerapan monolog P1 menonjolkan sifat beliau sebagai seorang pembuat keputusan utama yang tegas. Walaupun P1 mempamerkan ciri-ciri maskulin di dalam pertuturan, sifat membimbing juga diperlihatkan dalam beberapa situasi yang bersahaja melalui gurauan dan pertukaran jenaka peribadi bersama ahli yang lain. Fitur ini boleh mengukuhkan hubungan interpersonal yang sedia ada.

Gaya komunikasi P2 mengandungi kedua-dua ciri maskulin dan feminin dalam perbincangan. Ciri-ciri maskulin yang menekankan kawalan dan dominasi telah ditunjukkan melalui percanggahan langsung secara berdepan (head-on disagreements) dan pencelahan yang menamatkan giliran penutur semasa. Manakala ciri-ciri feminin yang menekankan hubungan interpersonal dan berasaskan kumpulan boleh dilihat melalui kaedah perundingan dalam membuat keputusan, persetujuan bersama dan giliran perkongsian idea yang sama rata. Monolog jarang berlaku dan interaksi lebih kerap berselang-seli dengan pertanyaan kepada ahli-ahli untuk maklum balas.

Gaya komunikasi P3 adalah bertentangan dengan P1. Dapatan kajian menunjukkan kekerapan sifat-sifat feminin yang konsisten melalui pola interaksi kolaboratif. Konsensus membentuk asas setiap keputusan dan corak perbincangan yang terdiri daripada kitaran cadangan, percanggahan pendapat dan penaakulan. Perbincangan cenderung untuk menjadi panjang, tetapi ianya produktif dan menjurus ke arah memenuhi objektif institusi dan keperluan ahli. P2 sentiasa bertolak ansur dalam memberi pandangan dan tidak kompetitif dengan ahli yang lain. Cadangan selalu dipertimbangkan manakala percanggahan sentiasa diberi dalam bentuk kompromi dan alasan yang logik. Tingkah laku komunikasi kolaboratif yang digunakan oleh P3 lebih menekankan pada menjaga hubungan dan keharmonian dalam hubungan dan bukan semata-mata untuk mencapai objektif mesyuarat.

\section{PERLAKUAN GENDER MELALUI WACANA PERBINCANGAN PENGURUSAN}

\section{Pengurus Akademik 1 (P1)}

P1 cenderung menggunakan ciri-ciri maskulin dalam tingkah laku pertuturan beliau. Ujarannya sentiasa menjurus ke arah ketepatan dan kejelasan idea dalam membincangkan sesuatu perkara. Objektif untuk mencapai keputusan yang sistematik dan praktikal menghasilkan interaksi yang jelas dan terbuka antara beliau dan ahli-ahli yang lain. Contohnya; 
(1) "Um, ambil yang utama dan kemudian mereka boleh bahagilah di bawahnya. Kalau tidak nampak macam kita tak organize."

(Um, just take the main one and then they can divide underneath it. If not we will appear disorganized.)

(2) jadi saya rasa kita cuba lakukan ini dengan menjelaskan kepada fakulti sains dulu [pertama] apa yang diperlukan dan seterusnya, dan kemudian kita satukannya, macamana dengan idea itu?

(so I think we try to do this by explaining to the science faculty first what is required and so on and then we bring them together, how about that?)

Perselisihan pendapat sentiasa dilakukan dengan cara lantang dan tegas, contohnya "Jangan! You CALL the meeting. You are the chairman what.. chairman ada kuasa".

Perkataan 'tidak' akan digunakan secara langsung sebagai reaksi kepada sesuatu yang bercanggah dengan pendapatnya. Sebagai contohnya, "No..no I think we should see the paper I think we should somehow see the paper together with Dr S first before dibawa ke MP" (Tidak..saya rasa kita perlu melihat artikel itu bersama Dr S sebelum dibawa ke MP). 'Tidak' akan disokong oleh alasan, misalnya "Tak, we have to minute. Besok susah kita tak tahu kan. So I think what we'll do. Because you have looked at it, you ask the perunding to kemaskemas"(Tak, kita perlu minitkan...Jadi saya rasa apa yang perlu kita lakukan. Sebab kamu dah lihat, kamu minta perunding to kemas-kemas) Pencanggahan pendapat dibuat secara sistematik. P1 menunjukkan arah yang jelas kepada ahli-ahli berkaitan pemahaman dan objektif beliau. P1 tahu apa yang dia diperlukan daripada ahli agar masa tidak dibazirkan dengan kesamaran dan keraguan. Alasan P1 sentiasa mempunyai pewajaran berdasarkan pengalaman beliau sebagai seorang pemimpin dan perbincangan mesyuarat terdahulu.

Maklumat dan anekdot dikongsikan bersama ahli-ahli sebagai salah satu cara untuk meraih sokongan mereka terhadap cadangannya.

P1 juga sentiasa memberikan idea baru yang berkaitan dengan laporan oleh ahli, contohnya,

\footnotetext{
"Saya punya, my mission is I want UKM to be the example pada other universities. Pasal masa saya bentangkan, semua org tengok, what is it, how is it you know, but I told them how it would be done you know. cara the external \& the internal. How do they work together to maintain the quality, but dalaman pun not everybody have a system. They may have somebody assign eh tapi universiti buat mungkin dia takda. So I think we should try and show we have PPA" (Misi saya adalah saya mahu UKM menjadi contoh kepada university lain. Pasal masa saya bentangkan, semua org tengok, apa dia, bagaimana, tapi saya beritahu mereka macamana untuk buat. Cara luaran dan dalaman. Macamana mereka kerja Bersama untuk kekalkan kualiti tapi dalam pun tak semua ada system. Mereka mungku ada lantik seseorang tapi Universiti buat mungkin dia takda. Jadi saya rasa kita tunjuk kita ada PPA).
}

Perbincangan di antara P1 dengan ahli-ahli yang lain sentiasa berorientasikan hasil dan tugasan, oleh itu bahasa yang digunakan tertumpu kepada kejelasan maklumat dan perancangan sistematik. Reaksi beliau kepada sesuatu perkara kerap dipaparkan dengan spontan, sebagaimana beliau tidak membuang masa dalam menyuarakan pendapat mengenai sesuatu perkara.

Kawalan permulaan topik selalu dimulakan oleh P1. Zimmerman dan West (1975) mendakwa bahawa lelaki lebih cenderung untuk menggunakan mekanisme memulakan dan mengawal topik perbualan yang akan membawa kepada penguasaan perbualan. Ciri-ciri linguistik ujaran P1 mencerminkan aspek ini dan beliau akan mendominasi separuh masa pertama perbincangan. Autoriti P1 sangat jelas daripada cara beliau membuat keputusan berkaitan sesuatu topik. Dominasi perbualan juga dapat dilihat menerusi pengagihan giliran perbincangan yang tidak sama rata di antara P1 dan ahli yang lain. Pendekatan berorentasikan pencapaian dalam perbincangan P1 juga ditunjukkan melalui kekerapan pencelahan beliau, soalan -wh (why did you go to Langkawi? Dimana mereka dapatkan input? Kumpulan mana 
yang buat?) dan cadangan beliau sentiasa dijustifikasikan oleh pengalaman peribadi dan rangkaian kenalan.

Jarang sekali terdapat penyuaraan perbezaan pendapat daripada ahli-ahli jabatan. Persetujuan cadangan P1 biasanya ditunjukkan oleh ahli melalui

(1) pengulangan idea "kita bubarkan semua dan adakan perlantikan ketua penjaminan. $\mathrm{Ni}$ kalau boleh kita structure ni dan kita terangkan, dan kita guna mereka ni'

(2) sokongan langsung dan penilaian, contoh 'Yes, for both, cause the idea is good- the idea is good' (Ya, untuk kedua-dua, sebab idea itu bagus - idea itu bagus)

(3) ringkasan idea, contoh 'Mengikut tanggungjawab'

(4) respon minimal seperti 'uhuh', 'ah' dan 'uhm' dan

(5) penerimaan idea serta tugasan.

P1 dilihat kurang memberi perhatian kepada keharmonian atau keselesaan hubungan antara beliau dan ahli-ahli yang lain. Perasaan mereka hanya dihargai apabila pendapat mereka sepadan dengannya. Sebaliknya, penaakulan logik dan pencapaian kata putus diberi keutamaan yang lebih daripada keperluan emosi individu.

Pentadbir Akademik 2 (P2)

Terdapat bukti linguistik yang menunjukkan dengan jelas perubahan ciri-ciri feminin dan maskulin dalam pertuturan P2 semasa beliau mempengerusikan mesyuarat.

Beberapa percanggahan pendapat berlaku di antara dua ahli untuk mendapatkan hasil yang adil dan seimbang untuk ahli-ahli lain yang dalam jabatan. Di sini, permintaan seorang ahli telah ditolak untuk memihak kepada permintaan yang akan memberikan manfaat kepada jabatan dan juga beberapa individu, contoh,

Z: tapi ada satu kumpulan. Boleh kita co-teach ke

S: Ah tak payahlah kalau satu kumpulan sahaja

Z: I minat macam sastera, terjemahan boleh lah

S: Tak apa. I mean, you should be able to teach

Kepentingan majoriti dilihat mengatasi kepentingan individu. Di sini beliau lebih fokus dalam memenuhi keperluan pengagihan beban kerja yang tidak sama rata sesama ahli. Matlamatnya dalam memelihara keseimbangan antara kerja dan hubungan di antara setiap ahli memberikan satu gambaran kepimpinan yang berorientasikan kumpulan, contohnya, "Kita lihat pada beban tugas pada semester pertama. Saya cuba utk menyelesaikan masalah beban tugas ni, tapi saya rasa sangat susah eh, sebab saya pun pertama kali mengendalikan beban tugas jabatan ini. Jadi saya ingin mendapatkan feedback dpd ahli2 lah untk menentukan beban tugas masing-masing.

Keputusan P2 juga berteraskan prinsip-prinsip kesaksamaan dan kecekapan. Beliau tidak takut untuk menyuarakan bantahan terhadap persoalan atau permintaan yang tidak munasabah. Hal ini ditunjukkan dalam ujaran "Sorry to interrupt ye, tapi saya rasa masalah ini dibincangkan sebelum. Disini bukan tempat utk membincangkan lagi tentang ah tapi saya rasa terpulang pd Pn K pun. Dalam su ..kertas kerja apa surat tu ada menyatakan dia punya band kan".

Ujaran yang digunakan jelas dan tepat dalam menyuarakan bantahan. Pada dasarnya, apabila wujud permintaan yang mengugat keseimbangan hasil perbincangan, bahasa yang digunakan menjurus ke arah pemulihan keseimbangan dan mewujudkan keputusan yang praktikal. Ada kalanya keputusan yang dibuat adalah berdasarkan kepada perbincangan di 
kalangan ahli-ahli kumpulan, contohnya dalam pembahagian kursus dan kelas. P2 mengakui bahawa beliau juga mengalami tugasan yang sukar dan meminta bantuan daripada ahli-ahli dalam pengagihan kursus dan kelas. Keputusan yang dibuat adalah berdasarkan kepada kompromi di antara ahli-ahli kumpulan dan juga keadaan. Apa yang dapat diperkatakan mengenai P2 adalah, keutamaan diletakkan pada keseimbangan, keperluan dan agenda mesyuarat, dan beliau tidak akan teragak-agak untuk memperlihatkan kuasanya jika diperlukan. Keputusan muktamad biasanya disuarakan oleh P2 selepas mendapat persetujuan dari ahli-ahli yang lain.

Terdapat penekanan terhadap perkataan 'kita' yang ditunjukkan melalui perundingan dan pendekatan berorentasikan kumpulan dalam membuat keputusan. Sebaliknya, terdapat juga bukti yang kukuh pada ujaran bantahan yang tegas dan orentasi terhadap pencapaian dalam strategi komunikasi P2. P2 juga jarang mendominasi perbualan. Sebaliknya, beliau membenarkan ahli-ahlinya menjadi penilai setiap situasi. Walau bagaimanapun, kata putus dalam membuat keputusan terletak pada beliau tetapi hanya berdasarkan apa yang telah dibincangkan oleh ahli-ahli kumpulan. Memandangkan beliau memberikan perhatian terhadap keperluan dan pendapat ahli-ahlinya, ujaran P2 juga memberi pendedahan dalam membuat keputusan dan menyelesaikan masalah berdasarkan logik dan pengalaman sebelumnya.

\section{Pentadbir Akademik 3 (P3)}

Ciri-ciri feminin banyak digunakan oleh P3. Jika kita lihat pada ujarannya dalam membuat keputusan, perbincangan dikendalikan menggunakan fitur kolaboratif yang konsisten. Keputusannya berdasarkan maklumat yang membawa kepada persepakatan dan bukannya berdasarkan kepada kuasa satu pihak sahaja. Satu contoh yang jelas ialah apabila mereka memutuskan untuk mengurangkan bilangan pengulas. Di sini, topik dimulakan oleh P3 yang diikuti dengan cadangan, penolakan, penaakulan logik dan berakhir dengan persetujuan bersama. Maklum balas terhadap cadangan biasanya dilakukan dengan berhemah oleh P3 dan ahli-ahli lain untuk menjaga air muka penutur. Sebagai contoh, apabila seseorang mengemukakan cadangan, ianya akan sentiasa diterima walaupun kadang kala terdapat alasan yang kukuh untuk penolakan. P3 akan sentiasa mempertimbangkan cadangan dan keutamaan penutur. Strategi komunikasi kolaboratif P3 lebih menekankan kepada menjaga hubungan baik beliau dan ahli berbanding pencapaian objektif mesyuarat. Gaya komunikasi ini adalah berorientasikan kumpulan.

P3 juga merupakan seorang individu yang mengambil berat tentang pendapat orang lain berhubung dengan tindakan beliau. Tingkah laku komunikasi beliau menggambarkannya sebagai seseorang yang membuat keputusan berdasarkan emosi penerima, status dan situasi semasa. Hasil perbincangan menjurus kepada memenuhi matlamat institusi serta memudahkan urusan ahli-ahli yang lain. P3 sentiasa bertolak ansur dalam memberikan sokongan dan kerjasama, dan tidak pernah kompetitif dalam pertuturannya. Apabila beliau mencadangkan susunan artikel, J bersetuju dengan menggunakan perkataan yang memberikan pujian dan penghargaan kepada P3 atas idea beliau "it's a good arrangement also, because yg the first few semua finance kan.. more or less"; "I think it's a good arrangement". Apabila P3 memberitahu F tentang keputusan untuk menamakan arikel J untuk satu anugerah, P3 memberikan pendapat peribadi terhadap kedua-dua artikel dan F segera bersetuju dengan keputusannya "Okay lah J, J lah"; "Okay boleh boleh". Ciri-ciri kolaboratif ini dapat memperkuatkan lagi hubungan yang sedia ada di antara P3 dan ahli-ahlinya.

Bukti hubungan rapat antara mereka jelas diperlihatkan dari gosip dan anekdot tentang seorang individu di jabatan, contoh, 
"I know his PhD class is conducted so vigorously you heard about that um? The students seem to want to be rid of him', "I was impressed with him lah. Oh all marketing people are good at impression management. Beware of them hahaha" (Saya tahu kelas $\mathrm{PhD}$ dia dijalankan dengan bersemangat. Kita dengar tentang itu? Pelajar macam nak singkirkan dia, "Saya kagum dengan dia. Oh semua orang pemasaran pandai mengurus impresi. Berhati-hatilah dengan mereka hahaha)

Apabila $\mathrm{F}$ menerima ulasan yang negatif daripada salah seorang penilai artikelnya, kedua-dua P3 dan $\mathrm{J}$ berusaha mencari jalan untuk menyokong $\mathrm{F}$ dengan memberikan tiga cadangan iaitu 1) supaya beliau meneliti semula artikel 2) menghantar artikel tersebut kepada penilai yang lain dan 3) penilai pertama telah membuat kesilapan memandangkan penilai kedua menerima artikel dengan sedikit pembetulan. P3 dan J membantu F menangani perasaan negatif melalui pelbagai cadangan dan galakan.

Walaupun P3 menonjolkan banyak ciri-ciri komunikasi feminin, beliau juga menggambarkan dirinya sebagai seorang yang berfikiran rasional. Hal ini terbukti dalam pendekatan deduktifnya dalam pengenalan topik yang dimulakan tanpa berlengah, diikuti dengan cadangan dan alasan yang kukuh. Meskipun terdapat percanggahan pendapat, P3 tetap berpegang pada pendapatnya walaupun keputusan akhir lazimnya berdasarkan persetujuan bersama.

\section{KESIMPULAN}

Dalam kajian tingkah laku pertuturan tiga pentadbir wanita ini, terdapat 3 gaya komunikasi yang berbeza. Dapatan jelas menunjukkan bahawa gender dan kumpulan etnik kurang mempengaruhi gaya pertuturan. Walaupun ketiga-tiga pentadbir adalah wanita dari kumpulan etnik yang sama, namun mereka mempunyai ciri-ciri tingkah laku pertuturan yang berbeza yang adakalanya menepati atau bercanggah dengan jangkaan perlakuan gender. Ujaran ketigatiga pentadbir dilihat berbeza-beza mengikut konteks, walaupun melakukan fungsi yang sama. Apa yang ingin diperlihatkan adalah konsep identiti feminin yang pelbagai, yang bukan sahaja dipengaruhi oleh gender, tetapi juga tuntutan kepemimpinan dan ekspresi keperibadian individu tersebut. Tingkah laku pertuturan mereka tidak mudah dikategorikan menggunakan teori gender yang sedia ada.

Konsisten dengan hujahan di awal kajian, ketiga-tiga pentadbir wanita ini berjaya mengadaptasi ciri-ciri feminin dan maskulin dalam pelbagai fungsi bahasa dalam mesyuarat, dalam usaha mereka untuk mencapai objektif institusi melalui demonstrasi kuasa dan pengukuhan hubungan interpersonal yang sedia ada. Ciri-ciri feminin dan maskulin digunakan mengikut keperluan situasi dan juga sebagai cerminan personaliti individu tersebut. Ketigatiga pentadbir sangat asertif dan dominan melalui cara mereka mencelah, mengajukan soalan untuk mengambil alih giliran dan mengawal topik, menyanggah pendapat secara langsung dan menggunakan logik untuk mencapai keputusan. Mereka juga menunjukkan ciri-ciri kolaboratif dalam membuat keputusan melalui kaedah perundingan, keputusan sebulat suara dan giliran percakapan yang sama rata.

Bahasa yang memberi keutamaan kepada perasaan ahli-ahli jabatan melalui perundingan dan pendekatan berorientasikan kumpulan, telah ditunjukkan dalam tingkah laku komunikasi P2 dan P3 tetapi kurang pada ujaran pertuturan P1. Sebaliknya, P1 lebih memberikan penekanan kepada ketepatan dan keputusan dalam komunikasi beliau. Bagi P2 pula, ujaran bahasa yang menunjukkan kejelasan dan berbentuk arahan hanya digunakan dalam situasi yang rumit. Apa yang jelas ialah ketiga-tiga pentadbir wanita ini telah menunjukkan fleksibiliti dan kebolehan mereka untuk beralih di antara mod maskulin dan feminin dalam komunikasi. Perbezaan bagaimanapun terletak pada kekerapan pengunaan fitur maskulin dan feminin oleh setiap pentadbir. P1 didapati kerap menggunakan ujaran berorientasikan objektif 
daripada P2 dan P3. P3 sebaliknya lebih cenderung kepada bahasa yang berasaskan rundingan. Walau bagaimanapun, pertuturan P3 adalah lebih seimbang berbanding P1 dan P2. Ciri-ciri bahasa yang asertif sentiasa diikuti dengan persetujuan bersama ahli-ahli. Kita dapat melihat kepelbagaian dalam gaya komunikasi dan amalan tiga individu dari satu kumpulan gender. Justeru itu, konsep feminin dan maskulin seharusnya dilihat sebagai konsep yang dinamik yang bebas diadaptasi dan mempunyai ruang untuk berkembang (Harrison 2008).

Dapatan kajian telah memperlihatkan konsep gender sebagai satu konstruk sosial yang sering kali diolah dalam tingkah laku pertuturan dan perlakuan sebagai tindak balas terhadap persekitaran dan keperluan situasi yang berbeza. Oleh itu identiti gender setiap individu sentiasa dalam proses adaptasi dan penyesuaian. Adalah penting bagi kita memahami dan menerima ciri-ciri maskulin dan feminin sebagai pelbagai sifat komunikatif dan tingkah laku yang boleh dimanfaatkan dan dimanipulasi oleh setiap individu un memenuhi konteks situasi, tujuan dan peranan yang dimainkan.

\section{RUJUKAN}

Bahiyah Abdul Hamid. 2003. English-Bahasa Melayu Code Alternation, Code Choice and Gender in Decision Making in Committee Meetings at an Institution of Higher Learning. Unpublished $\mathrm{PhD}$ Thesis, Universiti Kebangsaan Malaysia.

Bakic-Tomic, L., J. Dvorski, and A. Kirinic. 2015. Elements of teacher communication competence: An examination of skills and knowledge to communicate. International Journal of Research in Education and Science 1(2):157-166.

Balyer, A., and K. Özcan. 2017. Higher Education Administrators' Managerial Competency in Turkey. International Online Journal of Educational Sciences 9(4): 917-929.

Barnard, D. 2018. Common business English phrases for a workplace meeting. (Accessed July 14 https://virtualspeech.com/blog/english-phrases-workplace-meeting.

Butler, J. 1990. Gender Trouble: Feminism and the Subversion of Identity. London: Routledge.

Chen, S. 2010. Academic Administration: A Quest for Better Management and Leadership in Higher Education. Nova Science. New York.

Gaunt R. 2013. Breadwinning moms, caregiving dads: double standard in social judgments of gender norm violators. Journal of Family Issues 34(1): 3-24.

Goodale, M. 1987. The Language of Meetings: English Language Teacher at the United Nations in Geneva. Heinle. Boston.

Goman, C. K. 2016. Your Communication Style Dictated By Your Gender? Leadership Strategy. Accessed from https://www.forbes.com/sites/carolkinseygoman/2016/03/31.

Grant Thornton International. 2018. Women in business. International Business Report.

Harrison, S. 2008. Masculinities and Music: Engaging Men and Boys in Making Music. Newcastle: Cambridge Scholars Publishing.

Hines, S., and T. Sanger. 2010. Transgender Identities: Towards a Sociological Analysis of Gender Diversity. New York: Routledge.

Hofstede, G. 1991. Cultures and Organizations - Intercultural Cooperation and its importance for survival. London: Harper Collins Business.

Kachel, S., M. C. Steffens, and C. Niedlich. 2016. Traditional masculinity and femininity: Validation of a new scale assessing gender roles. Frontiers in Psychology 7: 956.

Kalargyrou, V., and R. Woods. 2009. What makes a college administrator an effective leader? An exploratory study. Journal of Teaching in Travel and Tourism 9(1-2), 21-36.

Koenig, A. M. 2018. Comparing Prescriptive and Descriptive Gender Stereotypes About Children, Adults, and the Elderly. Frontiers in Psychology 9:1086.

Kim, M. 1995. Intercultural Communication Theory. California: Sage Publications. 
Kivikangas J. M., J. Kätsyri, S. Järvelä, and N. Ravaja. 2014. Gender Differences in Emotional Responses to Cooperative and Competitive Game Play. PLoS ONE, 2014; 9 (7): e100318 https://doi.10.1371/journal.pone.0100318.

Lundquist and Misra. 2016. Making Meetings Less Miserable. https://www.insidehighered.com/advice. (accessed July 17, 2020)

Mayer, D. M. 2018. How Men Get Penalized for Straying from Masculine Norms. https://hbr.org/2018/10/how-men-get-penalized-for-straying-from-masculine. (accessed July 17, 2020)

Mazidah, K. U. 2013 Women's Speech Features Used by Character Margaret in The Iron Lady Movie. English Language and Literature Journal 1(1):1-5

Merchant, K. 2012. How Men And Women Differ: Gender Differences in Communication Styles, Influence Tactics, and Leadership Styles. CMC Senior Theses http://scholarship.claremont.edu/cmc_theses/513.

Oshagbemi, T. 1988. Leadership and Management in universities: Britain and Nigeria. New York: Walter De Gruyter.

Roa A., J. Sandler, D. Kelleher and C. Miller. 2018. Gender at Work: Theory and Practice for 21st Century Organizations. London, Routledge.

Rubin, J. Z., and B. R. Brown. 1975. The social psychology of bargaining and negotiation. New York: Academic Press.

Schiffrin, D. 1995. Discourse Analysis. Harlow: Longman.

Scheller-Boltz, D. 2017. The Discourse on Gender Identity in Contemporary Russia: An Introduction with a Case Study in Russian Gender Linguistics. Georg Olms Verlag.

Saran Kaur Gill. (1998). Asian and Global communication Skills for Women leaders. In

Asian Women Leaders in Higher Education. pp. 93-122. Bangi: Universiti Kebangsaan Malaysia.

Spoelma, J. 2018. What is Feminine Style Rhetoric and Why is it important? Communication,

Gender Differences. https://jenniferspoelma.com/blog-feed/feminine-style-rhetoric-whyimportant (accessed July 17, 2020)

Tannen, D. 2007. Talking voices: Repetition, dialogue and imagery in conversational discourse Cambridge University Press.

Zimmerman, D and C. West. 1975. Sex roles, interruptions and silences in conversation. In B.Thorne \& H.Henley (eds.) Language and Sex: Difference and Dominance. 2-5 Massachusetts: Newbury House.

KESUMAWATI ABU BAKAR

Fakulti Sains Sosial dan Kemanusiaan

Universiti Kebangsaan Malaysia

43600 UKM Bangi, Selangor, MALAYSIA

*Pengarang untuk surat-menyurat: kesuma@ukm.edu.my 